\title{
Nitrogen dose and sowing density in pea (Pisum sativum L.) crops, to obtain higher yields in Barranca [Dosis de nitrógeno y densidad de siembra del cultivo de arveja (Pisum sativum L.), para obtener mayor rendimiento en Barranca]
}

Mily Yolanda Ramirez Quiñones, Alberto Martin Medina Villacorta a(iD, Ritza Consuelo Collas Alva a , Jaime Braulio Cahuana Flores a(D), Andrea Rosario Pari Soto ${ }^{a}$ id, Andrea Luisa Pari Soto ${ }^{a}$ (D), Javier Eugenio Gómez Gamarra biD, Dante Daniel Cruz Nietoc, ${ }^{c}$ (D), José Yovera Saldarriaga a ${ }^{(i D)}$.

aUniversidad Nacional Santiago Antúnez de Mayolo, Perú

'Instituto de Educación Superior Tecnológico Público "Eleazar Guzmán Barrón", Perú cUniversidad Nacional José Faustino Sánchez Carrión, Perú

*daniel2262@hotmail.com

Received: 1 December 2021; Accepted: 02 January 2022; Published: 06 January 2022

\section{Resumen}

La investigación trata sobre dosis de nitrógeno y densidades de siembra de arveja. Objetivo fue determinar que dosis de nitrógeno y densidad de siembra obtuvo mayor rendimiento. La metodología se basa en investigación aplicada; por lo que, se empleó el modelo estadístico del Diseño de Bloques Completamente al Azar que constó 3 bloques y 6 tratamientos. Se aplicó las dosis a 17 días $1 / 2 \mathrm{~N}, 100 \% \mathrm{P}_{2} \mathrm{O}_{5}$ y $100 \% \mathrm{~K}_{2} \mathrm{O}$ y 62 días después de la siembra $1 / 2 \mathrm{~N}$, se evaluó desde siembra hasta cosecha y los datos se procesaron mediante análisis de varianza de dos factores y Duncan, se tomó muestras de hojas para análisis foliar y determinó la cantidad total de nitrógeno utilizado. Se determinó que $T_{5}$ destacó en longitud de tallo con $128.42 \mathrm{~cm}$, rendimiento comercial con $12.53 \mathrm{tn} / \mathrm{ha}$, $\mathrm{T}_{4}$ en peso de vainas con $620 \mathrm{~g}$, número de vainas por planta con 48, $\mathrm{T}_{6}$ en concentración de nitrógeno con $6.60 \mathrm{~g} / 100 \mathrm{~g}$ de materia seca y $\mathrm{T}_{5}$ en cantidad de nitrógeno utilizado con $154.3 \mathrm{~kg} / \mathrm{ha}$ que obtuvo mayor rendimiento. Se concluye, que la mayor dosis de nitrógeno y menor distanciamiento que es $T_{5}$ obtuvo mayor rendimiento superando en $24.52 \%$ en relación al $\mathrm{T}_{1}$.

Palabras clave: Dosis de nitrógeno; densidad de siembra; arveja; rendimiento.

\begin{abstract}
The research deals with nitrogen doses and sowing densities in peas. The objective was to determine which nitrogen dose and sowing density obtained the highest yield. The methodology is based on applied research; Therefore, the statistical model of the Completely Random Block Design was used, which consisted of 3 blocks and 6 treatments. The doses were applied at 17 days $1 / 2 \mathrm{~N}, 100 \% \mathrm{P}_{2} \mathrm{O}_{5}$ and $100 \% \mathrm{~K}_{2} \mathrm{O}$ and 62 days after sowing $1 / 2 \mathrm{~N}$, it was evaluated from sowing to harvest and the data were processed by analysis of variance of two factors and Duncan, took leaf samples for foliar analysis and determined the total amount of nitrogen used. It was determined that T5 stood out in stem length with $128.42 \mathrm{~cm}$, commercial yield with $12.53 \mathrm{tn} / \mathrm{ha}$, T4 in weight of pods with $620 \mathrm{~g}$, number of pods per plant with 48, T6 in nitrogen concentration with $6.60 \mathrm{~g} / 100 \mathrm{~g}$ of dry matter and T5 in the amount of nitrogen used with $154.3 \mathrm{~kg} / \mathrm{ha}$ that obtained the highest yield. It is concluded that the higher dose of nitrogen and less distance that is T5 obtained higher performance exceeding by $24.52 \%$ in relation to $\mathrm{T} 1$.
\end{abstract}

Keywords: Nitrogen dose; sowing density; pea; yield. 


\section{Journal of Sciences and Engineering}

Vol. 6, $\mathrm{N}^{\circ} 1,2022$

Copyright (c) 2022, CINCADER.

ISSN 2523-9503

DOI: https://doi.org/10.32829/sej.v6i1.156
Centre of Research and Training for

Regional Development

Online at www.journals.cincader.org

\section{Introduction}

By many, nitrogen compounds have been applied in a variety of ways and have inadequate spacing with the purpose of increasing the yield in vegetables, which has caused a reduction in yield, an increase in production cost, environmental pollution and economic loss. This is due to the fact that the constant use of synthetic nitrogen fertilizers generates nitrate residues that, due to their mobility, seep into the groundwater table and pollute. According to González (2019), he states that nitrogen is one of the primary nutrients, being the main limitation for agricultural productivity, since it is a constituent of enzymes, proteins, DNA, and chlorophyll; However, the main impacts of the excessive application of nitrogen are eutrophication, acidification and toxicity. Likewise, Gonzales et al. (2012), conclude that the sowing density influences the fruit yield, the lower the number of plants, the higher the number and weight of fruit per plant; but lower fruit yield per hectare.

Also, it is important to take into account the loss of nitrogen in the soil that, due to denitrification, volatilization, leaching, extraction by crops and the inadequate dose of synthetic nitrogen decreases the concentration, which is deficient in the availability of this nutrient and that causes lower performance and therefore economic loss. This analysis is supported by Larios-González et al. (2021), who conclude that nitrogen losses due to volatilization are considerably higher when the source is urea, regardless of the application method, which translates into a greater accumulated nitrogen loss.

Therefore, it is important to mention that in many cases soil analysis has been carried out in order to determine the appropriate dose of nitrogen; However, it is necessary to take into account the appropriate sowing spacing in order to increase yield, improve fruit quality, reduce contamination and therefore obtain greater economic profit. The analyzed is based on Feltrim et al. (2011), who states that to increase productivity in crops, a constant review of fertilization in relation to population density is required, due to the commercialization of new cultivars, the emergence of new growing regions and market characteristics of the vegetable.

It is worth mentioning that nitrogen influences the development of the plant presenting succulence, vigor and greenness; However, these qualities can be affected by the damage of pests and if the distance between plants is less, nutritional competition increases, which influence in reducing the yield and quality of the fruit. Therefore, it is necessary to determine an adequate dose and distance. This analysis is supported by Catalán (2016), who affirms that managing low sowing density: a high population of plants increases the environmental humidity of the crop and predisposes the plant to attack by pathogens.

Due to this situation, an investigation was carried out on what nitrogen doses and sowing density influence to obtain higher yields from pea crops in the province of Barranca. Therefore, the purpose was to determine the appropriate sowing dose and density to increase yield, reduce production cost, reduce environmental pollution and obtain greater economic profit.

\section{Materials and Methods}

\section{Kind of investigation}

The experiment is based on the type of applied and experimental research; Since by means of continuous evaluations of the samples and statistical analysis processing, it was determined which nitrogen dose is adequate and in which distance the highest pea yield was obtained.

\section{Location and weather conditions}

The investigation is located in the Supe Puerto district, Barranca province. Likewise, it is mentioned that to the north it limits Calle Alcantarilla, south Calle Leoncio Prado, east Jirón Pan de Azúcar and west Antigua Panamericana Norte. The climate conditions present Temperature 


\section{SE \\ Journal of Sciences and \\ Engineering}

Vol. 6, $\mathrm{N}^{\circ}$ 1, 2022
Copyright (c) 2022, CINCADER.

ISSN 2523-9503

DOI: https://doi.org/10.32829/sej.v6i1.156

\section{CINCADER}

Centre of Research and Training for

Regional Development

Online at www.journals.cincader.org

of $23-25^{\circ} \mathrm{C}$, Relative humidity $85-88 \%$ and altitude 84 m.a.s.l. (meters above sea level). See figure 1.

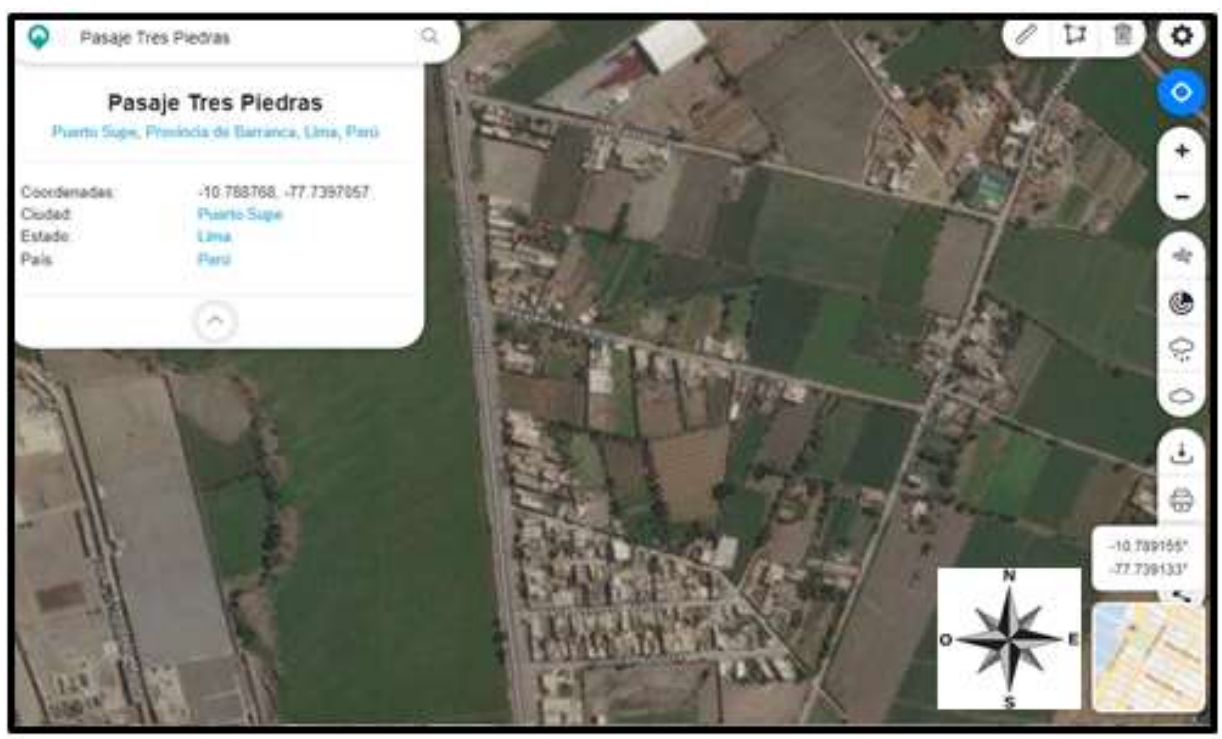

Figure 1. Location of the experimental area

Source: satellite-map.gosur.com, 2021

\section{Soil analysis}

To determine the concentration of nutrients in the soil, samples were taken in a staggered manner and from there it was poured into a blanket and the representative sample of $1 \mathrm{Kg}$ was taken and taken to the INIA (National Institute of Agrarian Innovation) - Huaral for analysis. The results determined that the $\mathrm{pH}$ was 7.13 which is neutral and does not present salt problems. Regarding the values of lower contraction, organic matter obtained $1.31 \%(2 \%-4 \%)$, nitrogen with $0.07 \%$ $(0.1 \%-0.2 \%)$, available phosphorus with $8 \%(12 \mathrm{ppm}-36 \mathrm{ppm})$ and potassium in normal concentration. with $92 \mathrm{ppm}$ (12 ppm - $250 \mathrm{ppm}$ ), calcium carbonate. Therefore, this soil presents a deficiency of macronutrients such as nitrogen, which is necessary to apply organic matter that favors the incorporation of nutrients for their availability. See table 1.

Table 1. Basic soil analysis, for pea cultivation

\begin{tabular}{|c|c|c|c|c|c|c|c|c|c|c|c|}
\hline \multirow{2}{*}{$\begin{array}{c}\text { E.C. } \\
(\mathrm{mS} / \mathrm{cm})\end{array}$} & \multirow[t]{2}{*}{$\begin{array}{c}\mathrm{pH} \\
1: 2.5\end{array}$} & \multirow{2}{*}{$\begin{array}{l}\text { O.M. } \\
(\%)\end{array}$} & \multirow{2}{*}{$\begin{array}{l}\mathrm{N} \\
(\%)\end{array}$} & \multirow{2}{*}{$\begin{array}{c}\mathrm{P} \\
(\mathrm{ppm})\end{array}$} & \multirow{2}{*}{$\begin{array}{c}\mathrm{K} \\
(\mathrm{ppm})\end{array}$} & \multirow[t]{2}{*}{$\begin{array}{c}\mathrm{CaCo}_{3} \\
(\%)\end{array}$} & \multicolumn{4}{|c|}{$\begin{array}{l}\text { Cation exchange } \\
\text { (mEq/100 g soil) }\end{array}$} & \multirow{2}{*}{ CEC } \\
\hline & & & & & & & $\mathrm{Ca}$ & $\mathrm{Mg}$ & $\mathrm{Na}$ & $\mathrm{K}$ & \\
\hline 1.50 & 7.13 & 1.31 & 0.07 & 8 & 92 & 0.88 & 15.06 & 0.87 & 0.19 & 0.24 & 16.36 \\
\hline
\end{tabular}

Source: INIA (2019), Basic soil fertility analysis for pea cultivation.

Note: E.C: Electrical conductivity

O.M.: Organic matter

mEq.: Milli equivalent

CEC: Cation exchange capacity

ppm: Parts per million 


\section{Journal of Sciences and Engineering}

Vol. 6, $\mathrm{N}^{\circ}$ 1, 2022

\section{Nitrogen in the soil}

According to the Kjeldahl method, the percentages of normal nitrogen values in the soil are $0.1 \%$ - 0.2\% (Egoávil, C, 2014). Therefore, this result indicates a low nitrogen concentration, which requires the incorporation of organic fertilizer. See table 2.

Table 2. Normal values of nitrogen in the soil

\begin{tabular}{lccc}
\hline Element & $\begin{array}{c}\text { Total concentration of } \\
\text { nitrogen compounds } \\
(\%)\end{array}$ & $\begin{array}{c}\text { Normal } \\
\text { values } \\
(\%)\end{array}$ & Calification \\
\hline Nitrogen & 0.07 & $01-0.2$ & Bajo \\
\hline Source: INIA (2019), Basic soil fertility analysis for pea cultivation
\end{tabular}

\section{Fertilization recommendation}

Regarding the fertilization dose, INIA - Huaral determined the recommended doses, which obtained the values detailed in table 3 . These were applied $1 / 2 \mathrm{~N}, 100 \% \mathrm{P}_{2} \mathrm{O}_{5}$ and $100 \% \mathrm{~K}_{2} \mathrm{O}$ at 17 and $1 / 2 \mathrm{~N}$ at 62 days after sowing, in the sources of total amount of Urea with $114.36 \mathrm{~kg}$, Diammonium Phosphate with $152.17 \mathrm{~kg}$ and 160 Potassium Sulfate. It is necessary to mention that Urea has $46 \% \mathrm{~N}$, Diammonium Phosphate $18 \% \mathrm{~N}$ and $46 \% \mathrm{P}_{2} \mathrm{O}_{5}$ and Potassium Sulfate $50 \%$ $\mathrm{K}_{2} \mathrm{O}$.

Table 3. Recommended dose for pea crops

\begin{tabular}{cccc}
\hline Culture & \multicolumn{3}{c}{ Dose (kg/ha) } \\
\hline \multirow{2}{*}{ Pea } & $\mathrm{N}$ & $\mathrm{P}_{2} \mathrm{O}_{5}$ & $\mathrm{~K}_{2} \mathrm{O}$ \\
& 80 & 70 & 80 \\
\hline
\end{tabular}

Source: INIA (2019), Basic soil fertility analysis for pea cultivation

\section{Study factor \\ Fertilization}

It includes the fertilization doses of the pea crop, which were formulated in three types according to the soil analysis. It is worth mentioning that only nitrogen concentrations were varied. See table 4.

Table 4. Nitrogen fertilization dose

\begin{tabular}{cc}
\hline Symbol & Nitrogen dose \\
\hline$F_{1}$ & $00-70-70$ \\
$F_{2}$ & $80-70-70$ \\
$F_{3}$ & $120-70-70$ \\
\hline
\end{tabular}

\section{Distancing}

Concerning the distance of the measurements between rows and between plants, the measurements that farmers in the area sow were taken into account. See table 5.

Table 5. Distance between furrow and between pea plant

\begin{tabular}{ccc}
\hline Symbol & Between row and plants & Plants per hectare \\
\hline$D_{1}$ & $1.5 \mathrm{~m}^{*}{ }^{*} 0.25 \mathrm{~m}$. & 53333 \\
$\mathrm{D}_{2}$ & $1.5 \mathrm{~m} .{ }^{*} 0.35 \mathrm{~m}$. & 38095 \\
\hline
\end{tabular}




\section{Journal of Sciences and \\ Engineering}

Vol. 6, $\mathrm{N}^{\circ}$ 1, 2022

Copyright (c) 2022, CINCADER.

ISSN 2523-9503

DOI: https://doi.org/10.32829/sej.v6i1.156

\section{CINCADER}

Centre of Research and Training for

Regional Development Online at www.journals.cincader.org

\section{Treatments}

The fertilization and spacing study factors were detailed, followed by grouping in an orderly manner and in this way the interactions were obtained. See table 6.

Table 6. Fertilization and sowing density of pea

\begin{tabular}{cc}
\hline Treatments & fertilization vs density \\
\hline$T_{1}$ & $\mathrm{~F}_{1}{ }^{*} \mathrm{D}_{1}$ \\
$\mathrm{~T}_{2}$ & $\mathrm{~F}_{1}{ }^{*} \mathrm{D}_{2}$ \\
$\mathrm{~T}_{3}$ & $\mathrm{~F}_{2}{ }^{*} \mathrm{D}_{1}$ \\
$\mathrm{~T}_{4}$ & $\mathrm{~F}_{2}{ }^{*} \mathrm{D}_{2}$ \\
$\mathrm{~T}_{5}$ & $\mathrm{~F}_{3}{ }^{*} \mathrm{D}_{1}$ \\
$\mathrm{~T}_{6}$ & $\mathrm{~F}_{3}{ }^{*} \mathrm{D}_{2}$ \\
\hline
\end{tabular}

Calculation of the amount of nitrogen in the soil

The weight of the arable shell was calculated with the following formula

$$
[\text { P.ha }]=(\text { Prof. } * \mathrm{~S} * \text { D.A. } * \text { Ha })
$$

Where:

[P.ha]: Topsoil weight per hectare

Prof: Soil depth $\left(0.25 \mathrm{~m}^{2}\right)$

S: Soil weight is $3500 \mathrm{tn}$

D.A: Apparent density $\left(1.4 \mathrm{~g} / \mathrm{cm}^{3}\right)$

Ha: $10000 \mathrm{~m}^{2}$

Then the organic carbon was calculated with the Van Bemmelen factor cited by (Vela et. Al., 2012)

\section{Where:}

$$
\text { [Org. C. }]=(0 . \mathrm{M} . \mathrm{x} \text { 0.58) }
$$

Org. C.: Organic Carbon

O.M.: Organic Material

Then the table of conversion factor from total nitrogen to available nitrogen (A.N.) was used.

Table 7. Total to available nitrogen conversion factor at $\mathrm{ppm}$ in relation to Carbon to nitrogen $(\mathrm{C} / \mathrm{N})$

\begin{tabular}{cc}
\hline Margin & Total Nitrogen conversion factor in percent, to \\
C/N ratio & Nitrogen in ppm \\
\hline Greater than 12 & 11.2 \\
From 10 to 12 & 140 \\
Under 12 & 225 \\
\hline
\end{tabular}

Source: Kass C.L D (1998), Soil fertility.

It was replaced and divided with $\mathrm{N}$ from the soil analysis, obtaining $\mathrm{C} / \mathrm{N}$

$$
\left.\frac{C}{N}=\frac{(1.31 . \times 0.58)}{0.07}=\right) \frac{0.76}{0.07}=10.85
$$




\section{Journal of Sciences and \\ Engineering}

Vol. 6, $\mathrm{N}^{\circ} 1,2022$

\section{GINGADER}

Centre of Research and Training for

Regional Development

Online at www.journals.cincader.org

Copyright @ 2022, CINCADER.

ISSN 2523-9503

DOI: https://doi.org/10.32829/sej.v6i1.156

The result was compared with the $\mathrm{C} / \mathrm{N}$ ratio margin (table 7), the operation was carried out obtaining available nitrogen from the soil (table 1): ND $=0.07 * 140 \mathrm{ppm}=9.8 \mathrm{ppm}$ and then the relationship with [P.ha ] obtaining $34.3 \mathrm{Kg}$ of Nitrogen in soil.

\section{Procedures}

The procedures were carried out as follows:

- Soil samples were taken in a staggered manner and from there $1 \mathrm{~kg}$ of representative soil was taken and sent to the INIA-Huaral laboratory.

- Once the results of the soil analysis were obtained, the nitrogen doses and two spacings that farmers in the area sow were formulated. These were combined in an orderly manner for each treatment. See table 6.

- Then the statistical model of the Completely Random Block Design with Factorial arrangement was used, which was delimited into three blocks and 6 treatments.

- Then the plots were delimited at $5.25 \mathrm{~m}$ and $4.5 \mathrm{~m}$ and they were sown according to the distances detailed in table 5. Also, 17 days after sowing, $1 / 2 \mathrm{~N}, 100 \% \mathrm{P}_{2} \mathrm{O}_{5}$ and $100 \% \mathrm{~K}_{2} \mathrm{O}$ were applied. 62 days after servant $1 / 2 \mathrm{~N}$.

- From there, the evaluations of each sample were carried out and the data were processed through statistical analysis.

- Finally, leaf samples were taken for foliar analysis, which allowed determining which nitrogen concentration influenced to obtain higher yields.

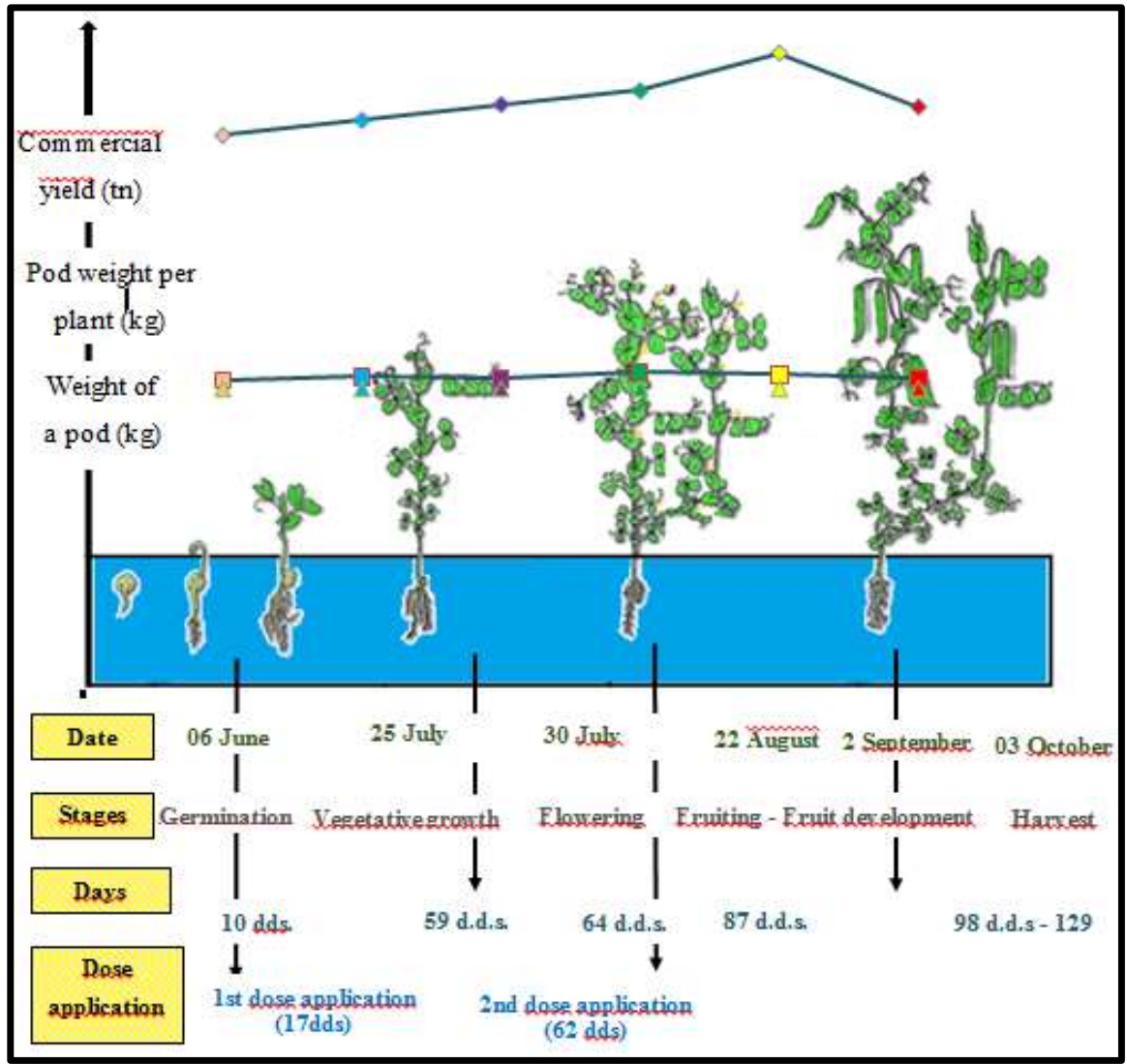

Figure 2. Date of evaluation and application of nitrogen doses 


\section{Journal of Sciences and Engineering}

Vol. 6, $\mathrm{N}^{\circ}$ 1, 2022

Copyright (c) 2022, CINCADER.

ISSN 2523-9503

DOI: https://doi.org/10.32829/sej.v6i1.156

\title{
3. Results
}

\begin{abstract}
Stem length
After the two-factor analysis of variance of the stem length that is detailed in table 8, it was determined that there was significance in the interaction; that is, the nitrogen fertilization doses and sowing density influenced the stem length, which showed statistical differentiation and T4 stood out with $12.8 .42 \mathrm{~cm}$. Therefore, it is analyzed that at a higher dose of nitrogen and a lower sowing density, this nutrient was used in an optimal way, influencing the development of the plant and its architecture. This analysis is supported by BID et al., (2020), who affirm that the application of nutrients and their effect on yields is variable, and depends on various factors such as the cultivation site, the previous soil conditions, the time of application, sowing density, etc.
\end{abstract}

Table 8: Results of the physical characteristics of the treatments

\begin{tabular}{|c|c|c|c|c|c|c|c|c|}
\hline \multicolumn{2}{|c|}{ Treatment } & $\begin{array}{l}\text { Stem length } \\
(\mathrm{cm})\end{array}$ & $\begin{array}{c}\text { Treatme } \\
\text { nt }\end{array}$ & $\begin{array}{l}\text { Pod weight } \\
\text { per plant (g) }\end{array}$ & $\begin{array}{c}\text { Treatme } \\
\text { nt }\end{array}$ & $\begin{array}{l}\text { Number of } \\
\text { pods per } \\
\text { plant }\left(\mathrm{N}^{\circ}\right)\end{array}$ & $\begin{array}{l}\text { Treatm } \\
\text { ent }\end{array}$ & $\begin{array}{c}\text { Performance } \\
\text { Commercial } \\
\text { (tn) }\end{array}$ \\
\hline$T_{5}$ & $\mathrm{~F}_{3}{ }^{*} \mathrm{D}_{1}$ & $128.423 \mathrm{a}$ & $\mathrm{T}_{4}$ & $620.0 \mathrm{a}$ & $\mathrm{T}_{4}$ & $47.644 \mathrm{a}$ & $T_{5}$ & $12.537 \mathrm{a}$ \\
\hline $\mathrm{T}_{4}$ & $\mathrm{~F}_{2}{ }^{*} \mathrm{D}_{2}$ & $125.302 \mathrm{ba}$ & $T_{5}$ & $536.5 \mathrm{a}$ & $\mathrm{T}_{2}$ & $46.222 \mathrm{a}$ & $\mathrm{T}_{4}$ & $11.123 \mathrm{a}$ \\
\hline $\mathrm{T}_{2}$ & $F_{1} * D_{2}$ & $122.352 \mathrm{bac}$ & $\mathrm{T}_{2}$ & $450.4 \mathrm{a}$ & $T_{6}$ & $43.866 \mathrm{a}$ & $\mathrm{T}_{3}$ & $10.615 a$ \\
\hline$T_{6}$ & $\mathrm{~F}_{3}{ }^{*} \mathrm{D}_{2}$ & 121.632 bc & $T_{6}$ & $422.8 \mathrm{a}$ & $T_{5}$ & $40.222 \mathrm{a}$ & $T_{6}$ & $10.530 \mathrm{a}$ \\
\hline$T_{3}$ & $F_{2}{ }^{*} D_{1}$ & $118.963 \mathrm{bc}$ & $T_{3}$ & $380.5 \mathrm{a}$ & $\mathrm{T}_{1}$ & $38.733 \mathrm{a}$ & $T_{2}$ & $10.024 \mathrm{a}$ \\
\hline$T_{1}$ & $F_{1} * D_{1}$ & $116.978 \mathrm{c}$ & $T_{1}$ & $334.7 \mathrm{a}$ & $T_{3}$ & $38.355 a$ & $\mathrm{~T}_{1}$ & $9.463 \mathrm{a}$ \\
\hline \multicolumn{2}{|c|}{ Significance } & * & & $* *$ & & ** & & $* *$ \\
\hline \multicolumn{2}{|c|}{ VC \% } & $2.7 \%$ & & $35.97 \%$ & & 15.96356 & & $15.57 \%$ \\
\hline
\end{tabular}

Note: VC \% (Percentage of coefficient of variation)

\section{Pod weight per plant}

Regarding the statistical analysis of pod weight per plant that is seen in table 8, it was determined that there was no significance in the interaction; that is, the nitrogen doses and sowing density did not obtain statistical differentiation. Therefore, it is interpreted that the nitrogen doses and sowing density did not influence the use and strengthening of the plant, which did not increase pod yield. However, the T4 with $620 \mathrm{~g}$ of pods stood out in relation to the others. Therefore, it is analyzed that at an adequate dose of nitrogen and sowing density, it obtained greater availability of this nutrient, influencing its development and resistance to stress factors, thus obtaining higher yields. This analysis is based on Mas, F. (2007) who determined that the adequate dose of nitrogen and phosphate fertilization, based on various forms of fertilization and densities in beans. According to the results, the variables number of pods per plant and weight of 100 grains were higher in the densities of 200,000 and 250,000 plants/ha.

\section{Number of pods per plant}

Regarding the statistical analysis of the number of pods per plant that is detailed in table 8 , it can be seen that there was no significance; which means that the nitrogen doses and sowing density did not influence the number of pods. However, the T4 with 48 pods stood out in relation to the other treatments. This result is interpreted that at an adequate dose of nitrogen and higher sowing density, a greater number of pods were obtained. Which is analyzed that at higher sowing density this nutrient was used in an optimal way, influencing the development of the plant, resistance to stress factors and obtaining higher yields. This analysis is based on García \& Calderón (2021), who determined that at 4900 plants/ha the highest yield $(2611 \mathrm{~kg} / \mathrm{ha})$, harvest index $(0.19)$ and pods per plant (125), in relation to 3267 plants/ha and 2450 plants/ha. 


\section{Journal of Sciences and Engineering}

Vol. 6, $\mathrm{N}^{\circ}$ 1, 2022

\section{Business performance}

Corresponding to the statistical analysis of commercial performance that is observed in table 8 , it is indicated that there was no significance in the interactions; mentioned in another way, nitrogen doses and spacing did not influence performance; However, at a higher dose of this nutrient and a lower sowing density, which is T5, it obtained 12,537 tn/ha, which stood out in relation to the other treatments. Therefore, it is interpreted that the higher the dose of this nutrient and the lower the sowing density, the yield increased to $24.52 \%$ in relation to the control (T1). Consequently, at this dose of nitrogen and spacing, nitrogen was used optimally and promoted the absorption of other nutrients for the development of the plant and therefore in the increase of yield. The analysis is supported by Calero et al. (2018) who determined that the best results were achieved by the density of 200,000 plants/ha and increased productivity by 1.97, 0.38 and $1.29 \mathrm{tn} / \mathrm{ha}$, with respect to the other evaluated densities of 160,000,180,000 and 220,000 plants/ha. Likewise, Ramírez (1984), investigated on different doses of nitrogen, $200 \mathrm{~kg} \mathrm{~N}, 0 \mathrm{~kg} / \mathrm{ha}$ and phosphorus $0 \mathrm{~kg} \mathrm{~N}$, $120 \mathrm{~kg} \mathrm{P} \mathrm{O}_{5} / \mathrm{ha}$, determining that the highest production was obtained with $1231.6 \mathrm{~kg} / \mathrm{ha}$ and with levels of $0 \mathrm{~N}$ and $120 \mathrm{~kg} \mathrm{P} \mathrm{O}_{5} / \mathrm{ha}$ obtained $975.9 \mathrm{~kg} / \mathrm{ha}$ of beans.

\section{Leaf analysis by treatment}

Regarding the foliar analysis carried out at INIA - Huaral, which details the data in table 9, it indicates that the T6 obtained $6.60 \mathrm{~g}$ of nitrogen in $100 \mathrm{~g}$ of dry matter; however, this concentration did not stand out in performance; since the T5 with $5.96 \mathrm{~g}$ of nitrogen in $100 \mathrm{~g}$ of dry matter stood out with $12,537 \mathrm{tn} / \mathrm{ha}$. Therefore, at this dose of nitrogen and sowing density, it obtained the normal concentration qualification of this nutrient in leaves, which indicates that it was used in an optimal way and that it influenced the development and therefore the yield of the pea crop. The analysis is supported by FAO, (2002) that mentions nitrogen is the engine of plant growth. Supplement one to four percent of the dry extract of the plant. Which is absorbed from the soil in the form of nitrate $\left(\mathrm{NO}_{3}{ }^{-}\right)$or ammonium $\left(\mathrm{NH}_{4}{ }^{+}\right)$and is an essential constituent of proteins, it is involved in all the main processes of plant development.

Table 9: Nitrogen concentration results by treatment

\begin{tabular}{cccccc}
\hline Treatments & Interactions & Results $(\%)$ & Qualification & $\begin{array}{c}\text { Normal } \\
\text { Values }\end{array}$ & $\begin{array}{c}\text { Performance } \\
\text { (tn/ha) }\end{array}$ \\
\hline$T_{1}$ & $\mathrm{~F}_{1}{ }^{*} \mathrm{D}_{1}$ & 3.45 & Low & $4.50-6.00$ & 9.463 \\
$\mathrm{~T}_{2}$ & $\mathrm{~F}_{1}{ }^{*} \mathrm{D}_{2}$ & 2.98 & Low & $4.50-6.00$ & 10.024 \\
$\mathrm{~T}_{3}$ & $\mathrm{~F}_{2}{ }^{*} \mathrm{D}_{1}$ & 5.20 & Normal & $4.50-6.00$ & 10.615 \\
$\mathrm{~T}_{4}$ & $\mathrm{~F}_{2}{ }^{*} \mathrm{D}_{2}$ & 5.45 & Normal & $4.50-6.00$ & 11.123 \\
$\mathrm{~T}_{5}$ & $\mathrm{~F}_{3}{ }^{*} \mathrm{D}_{1}$ & 5.96 & Normal & $4.50-6.00$ & 12.537 \\
$\mathrm{~T}_{6}$ & $\mathrm{~F}_{3}{ }^{*} \mathrm{D}_{2}$ & 6.60 & High & $4.50-6.00$ & 10.530 \\
\hline
\end{tabular}

Source: INIA (2019), Analysis of percentage of nitrogen in leaves.

\section{Nitrogen contribution}

Concerning the concentration of nitrogen in the soil that is detailed in table 10, the amount was determined by means of soil analysis and with the Van Bemmelen method and converted with the conversion factor from total nitrogen to available to $\mathrm{ppm}$ in relation to carbon. To nitrogen, $34.3 \mathrm{Kg} / \mathrm{ha}$ of available nitrogen was obtained and added with the additional dose of $120 \mathrm{Kg} / \mathrm{ha}$ of nitrogen obtained $154.3 \mathrm{Kg} / \mathrm{ha}$ of nitrogen which is the total used and that at a lesser distance between $0.25 \mathrm{~m}$ between plant and $1.5 \mathrm{~m}$ between rows, which is T5, stood out in higher yield with $12537 \mathrm{tn} / \mathrm{ha}$ of pea. Therefore, in this low nitrogen percentage soil condition, the application of nitrogen doses and at this sowing density influenced the development of the plant, improved resistance to stress factors and therefore increased yield. The analysis is based on Rennie and 


\section{Journal of Sciences and Engineering}

Vol. 6, $\mathrm{N}^{\circ}$ 1, 2022

Copyright @ 2022, CINCADER.

ISSN 2523-9503

DOI: https://doi.org/10.32829/sej.v6i1.156

Dubetz, (1986) and Prieto (2010), they state that the nitrogen fixation capacity of peas is usually very high. Contributions of up to $185 \mathrm{~kg} / \mathrm{ha}$ have been measured in this way.

Table10. total nitrogen used per treatment for the pea crop

\begin{tabular}{cccccc}
\hline Treatment & Interaction & Nitrogen dose & $\begin{array}{r}\text { Nitrogen in the } \\
\text { soil }\end{array}$ & $\begin{array}{r}\text { Total nitrogen } \\
\text { used }\end{array}$ & $\begin{array}{c}\text { Performance } \\
(\mathrm{Kg} .)\end{array}$ \\
\hline $\mathrm{T}_{1}$ & $\mathrm{~F}_{1} \mathrm{D}_{1}$ & 0 & 34.3 & 34.3 & 9463 \\
$\mathrm{~T}_{2}$ & $\mathrm{~F}_{1} \mathrm{D}_{2}$ & 0 & 34.3 & 34.3 & 10024 \\
$\mathrm{~T}_{3}$ & $\mathrm{~F}_{2} \mathrm{D}_{1}$ & 80 & 34.3 & 114.3 & 10615 \\
$\mathrm{~T}_{4}$ & $\mathrm{~F}_{2} \mathrm{D}_{2}$ & 80 & 34.3 & 114.3 & 11123 \\
$\mathrm{~T}_{5}$ & $\mathrm{~F}_{3} \mathrm{D}_{1}$ & 120 & 34.3 & 154.3 & 12537 \\
$\mathrm{~T}_{6}$ & $\mathrm{~F}_{3} \mathrm{D}_{2}$ & 120 & 34.3 & 154.3 & 10530 \\
\hline
\end{tabular}

\section{Conclusions}

- It was determined that the fertilization dose $\mathrm{N}: 120-\mathrm{P}_{2} \mathrm{O}_{5}: 70$ and $\mathrm{K}_{2} \mathrm{O}: 70 \mathrm{~kg} / \mathrm{ha}$ and distance between furrows $1.5 \mathrm{~m}$. and between plants at $0.25 \mathrm{~m}$, it obtained the highest yield with $12.53 \mathrm{tn} / \mathrm{ha}$ of pea. Therefore, at this dose of nitrogen and spacing, this nutrient was used in an optimal way, which influenced the development of the plant, protection against stress and therefore increased yield.

- Nitrogen concentration in pea leaves was also determined, which highlighted the T6 with $6.60 \mathrm{~g}$ of nitrogen in $100 \mathrm{~g}$ of dry matter; however, this concentration did not influence performance; Therefore, T5 with $5.96 \mathrm{~g}$ of nitrogen in $100 \mathrm{~g}$ of dry matter in normal rating obtained the highest performance. Consequently, this concentration of this nutrient is taken as an indicator in which it was used in an optimal way and a higher yield was obtained.

- Finally, the amount of nitrogen available in the soil was determined, which is $34.3 \mathrm{Kg} / \mathrm{ha}$ and adding $120 \mathrm{Kg}$ of nitrogen / ha with a total of $154.3 \mathrm{Kg} / \mathrm{ha}$ and $1.5 \mathrm{~m}$ distance between furrows. and between plants at $0.25 \mathrm{~m}$, which is the T5, stood out in higher yield of the pea crop. Therefore, this amount of nitrogen used did not harm performance, on the contrary, it influenced development and performance.

\section{References}

BID, Procomer, Crecimiento verde, \& Esencial Costa Rica, 2020, Manual técnico: Siembra de Pitahaya. Procomer - Costa Rica, pp. 1-60. https://www.procomer.com/wpcontent/uploads/Manual-de-siembra-pitahaya.pdf

Calero Hurtado A., Castillo Y., Quintero E., Pérez Y., Olivera D., 2018, Efecto de cuatro densidades de siembra en el rendimiento agrícola del frijol común (Phaseolus vulgaris L.). Revista de la Facultad de Ciencias, Vol. 7, $\mathrm{N}^{\circ}$ 1, pp. 88 - 100. DOI: https://doi.org/10.15446/rev.fac.cienc.v7n1.67773

Catalán W., 2016, Informe final servicio de consultoría para el análisis sobre organismos y microorganismos del aire y suelo del maíz. Ministerio del Ambiente Dirección General de Diversidad Biológica-DGDB, 1-117. https://bioseguridad.minam.gob.pe/wpcontent/uploads/2017/02/maiz_microsuelo_aire.pdf

Egoávil, C, 2014, Caracterización de suelos con fines de fertilidad en la provincia de Satipo Junín - Perú. AVSI Pp. 1-34. https://www.devida.gob.pe/documents/20182/335287/4.+Caracterización+de+Suelos_AVSI .pdf/411a6ca2-4d1a-4497-9012-2e1d2d3b9a33 


\section{Journal of Sciences and Engineering}

Vol. 6, $\mathrm{N}^{\circ} 1,2022$
Centre of Research and Training for

Regional Development

Online at www.journals.cincader.org

Copyright @ 2022, CINCADER.

ISSN 2523-9503

DOI: https://doi.org/10.32829/sej.v6i1.156

FAO, 2002, Los fertilizantes y su uso, FAO (Organización de las Naciones Unidas para la Alimentación y la Agricultura), IFA (Asociación Internacional de los Fertilizantes), pp. 1-77. https://www.fao.org/3/x4781s/x4781s.pdf

Feltrim A., Cecílio A., Vinicius M., Pavani L., Barbosa J., Mendoza J., 2011, Distancia entre plantas y dosis de nitrógeno y potasio en sandía sin Semillas fertirrigada. Pesquisa Agropecuária Brasileira, Vol. 46, N 9, pp. 985 - 991. https://doi.org/10.1590/S0100204X2011000900003

García Abarca E., \& Calderón Cerdas R., 2021, Influencia de la densidad de siembra sobre producción y desarrollo de mucuna (Mucuna puriens L. DC). Revista agronomía Costarricense, Vol. 45, N² 2, pp. 103-113. https://doi.org/10.15517/rac.v45i2.47771

Gonzales R., Imán S., Pinedo E., 2012, Evaluación de densidades de siembra en Solanum sessiliflorum Dunal "cocona" y su efecto en el rendimiento de fruto. Revista Ciencia Amazónica (lquitos), Vol. 2, № 2, pp. 142 -145. https://doi.org/10.22386/ca.v2i2.38

González, P., 2019, Consecuencias ambientales de la aplicación de fertilizantes. Asesoría técnica parlamentaria, pp. 1-5. https://obtienearchivo.bcn.cl/obtienearchivo?id=repositorio/10221/27059/1/Consecuencias_ ambientales_de_la_aplicacion_de_fertilizantes.pdf

Instituto Nacional de Innovación Agraria (INIA-Huaral), 2019, Hoja Análisis de Foliar en el cultivo de arveja. INIA - Huaral. Perú. Página 1.

Instituto Nacional de Innovación Agraria (INIA-Huaral), 2019, hoja de análisis de porcentaje de nitrógeno en hojas. INIA - Huaral. Perú. Página 1.

Kass C.L D, 1998, Fertilidad de suelos. EUNED (Editorial Universidad Estatal a Distancia), Editado por Jorge Núñez Solís. Primera edición. San José, Costa Rica. Página 205. https://books.google.com.pe/books?id=sRua411 JhvgC\&pg=PP8\&dq=KASS+FERTILIDAD + DE+SUELOS\&hl=es\&sa=X\&ved=2ahUKEwiQ_p2Tx_rOAhU_qZUCHcNUAwQQ6AF6BAg HEAl\#v=onepage\&q=KASS\%20FERTILIDAD\%20DE\%20SUELOS\&f=false

Larios-González R., García Centeno L., Jerónimo Ríos M., Avalos Espinoza C., Castro Salazar J., 2021, Pérdidas de nitrógeno por volatilización a partir de dos fuentes nitrogenadas y dos métodos de aplicación. Revista Siembra, Vol. 8, № 2, pp: e 2475. https://doi.org/10.29166/siembra.v8i2.2475

Mas, F., 2007, Estudio exploratorio sobre densidades de siembra y el sitio de aplicación de diferentes niveles de nitrógeno y fosforo en el rendimiento de frijol (Phaseolus vulgaris L.) Variedad Icta Ligero en el parcelamiento Cuyuta, Masagua, Escuintla. Thesis to Opt for the Title of Agricultural Engineering in Agricultural Production Systems. Universidad de San $\begin{array}{llll}\text { Carlos de Guatemala. } & \text { Guatemala. } & \end{array}$ http://biblioteca.usac.edu.gt/tesis/01/01_1812.pdf

Prieto G., 2010, Pautas para el manejo del cultivo de Arveja AER INTA Arroyo Seco. Instituto Nacional de Tecnología Agropecuaria - Argentina. https://inta.gob.ar/sites/default/files/script-tmp-pautas-para-el-manejo-del-cultivo-de-arvejafinal.pdf

Ramírez G., 1984, Efecto de la Fertilización con Nitrógeno y Fosforo del Frijol común (Phaseolus vulgaris) en un suelo de Upala. Revista Agronomía Costarricense, Vol. 8, № 1, pp. 69-73. https://www.mag.go.cr/rev_agr/v08n01_069.pdf

Rennie y Dubetz, 1986, Nitrogen-15-Determined Nitrogen Fixation in Field-Grown Chickpea, Lentil, Fababean, and Field Pea. Agron. J. 78:654-660

Satellite-map.gosur, 2021, Ubicación del área experimental. https://satellitemap.gosur.com/es/?mylocation $=1 \& \|=-10.788725651300027,-$

$77.74078347146394 \& z=16.126643263286034 \& t=$ satellite

Vela G., López J., Rodríguez M., 2012, Niveles de carbono orgánico total en el Suelo de Conservación del Distrito Federal, centro de México. Revista Investigaciones geográficas, Vol. 77, pp. 18-30. http://www.scielo.org.mx/scielo.php?script=sci_arttext\&pid=S018846112012000100003 